Biogeosciences Discuss., https://doi.org/10.5194/bg-2018-112

Manuscript under review for journal Biogeosciences

Discussion started: 16 March 2018

(c) Author(s) 2018. CC BY 4.0 License.

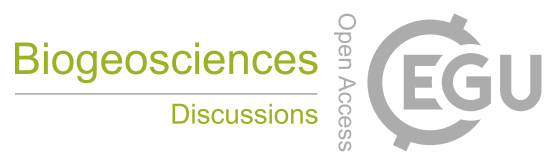

(c) (i)

1

2

3

4

5

6

\title{
Global patterns of leaf nutrient resorption in herbaceous plants
}

\author{
Zhiqiang Wang $^{1 * \#}$, Zhexuan Fan $^{2 *}$, Qi Zhao ${ }^{1}$, Jinzhi Ran ${ }^{3 *}$, Karl J. Niklas ${ }^{4}$ \\ ${ }^{1}$ The Institute for Advanced Study, Chengdu University, Chengdu 610106, China; \\ ${ }^{2}$ State Key Laboratory of Biocontrol, School of Life Sciences, Sun Yat-Sen \\ University, Guangzhou 510006, China; \\ ${ }^{3}$ State Key Laboratory of Grassland and Agro-Ecosystems, School of Life Sciences \\ Lanzhou University, Lanzhou 730000, China; \\ ${ }^{4}$ Plant Biology Section, School of Integrative Plant Science, Cornell University, \\ Ithaca, New York 14853, US \\ *Corresponding author: Dr. Zhiqiang Wang, Dr. Jinzhi Ran \\ \# These authors contributed equally to this paper \\ Email: wang-zq@hotmail.com, ranjz@1zu.edu.cn
}

Tel: +86-13228121691

Fax: +86-028-84616040 
Biogeosciences Discuss., https://doi.org/10.5194/bg-2018-112

Manuscript under review for journal Biogeosciences

Discussion started: 16 March 2018

(c) Author(s) 2018. CC BY 4.0 License.

Abstract. Nutrient resorption plays an important role in plant ecology because it plays a key role in nutrient conservation strategies of plants. However, our current knowledge about the patterns of nutrient resorption among herbaceous species at a global scale is still inadequate. Here, we present a meta-analysis using a global dataset of nitrogen $(\mathrm{N})$ and phosphorus $(\mathrm{P})$ resorption efficiency spanning 521 observations and 248 herbaceous species. This analysis shows that the $\mathrm{N}$ resorption efficiency (NRE) and P resorption efficiency (PRE) across all herbaceous plant groups are 54.7\% and $64.5 \%$, respectively. Across all species, NRE, PRE and N:P resorption ratios (NRE:PRE) vary statistically significantly at a global scale, i.e., NRE, PRE and NRE:PRE increase with increasing latitude but decrease with increasing mean annual temperature (MAT) and mean annual precipitation (MAP). For different functional groups, similar patterns of NRE, PRE and NRE:PRE with respect to latitude, MAT and MAP are observed. Our study are very important complementary to global-scale studies of nutrient resorption and also can inform attempts to model biogeochemical cycling at a global scale.

Key words: global scale, nutrient resorption, latitude, temperature and precipitation, herbaceous species 
Biogeosciences Discuss., https://doi.org/10.5194/bg-2018-112

Manuscript under review for journal Biogeosciences

Discussion started: 16 March 2018

(c) Author(s) 2018. CC BY 4.0 License.

\section{Introduction}

53 Nutrient resorption, that is, internal nutrient recycling is recognized as most important

54 mechanisms of nutrient conservation that permits plants to re-use nutrients directly and reduces a dependence on external nutrient supplies especially in nutrient-poor environment (Aerts, 1996; Aerts and Chapin, 1999). This conservation mechanism can affect many ecosystem processes such as plant competition, nutrient uptake, reproduction, and carbon cycling (Killingbeck, 1996; Berg and McClaugherty, 2008; Richardson et al., 2008; Zhang et al., 2013). Thus, a quantitative understanding the nutrient resorption patterns of plants would offer insights into plant nutrient limitations (Güsewell, 2004; Richardson et al., 2008), possibly the different response of plants to multiple global changes (Yuan and Chen, 2009a; Reed et al., 2012) and nutrient cycling (Aerts and Chapin, 1999; Chapin et al., 2011).

Nutrients such as nitrogen $(\mathrm{N})$ and phosphorus $(\mathrm{P})$ are the main nutrients most frequently restricting plant growth and production globally (Chapin, 1980; Güsewell, 2004), the resorption of $\mathrm{N}$ and $\mathrm{P}$ are paramount importance to plant nutrient conservation (Killingbeck, 1996; Kobe et al., 2005). N and P resorption are often presented as two important indices of internal nutrient recycling in plants, resorption efficiency of $\mathrm{N}(\mathrm{NRE})$ and $\mathrm{P}$ (PRE), which defined as the proportional resorbed of $\mathrm{N}$ and $\mathrm{P}$ during leaves senescence: $\mathrm{NRE}$ or $\mathrm{PRE}=[(\mathrm{N}$ or $\mathrm{P}$ in green leaves $-\mathrm{N}$ or $\mathrm{P}$ in senesced leaves) $/ \mathrm{N}$ or P in green leaves] $\times 100 \%$ (Killingbeck, 1996; Kobe et al., 2005; Yuan and Chen, 2009a).

Significant increase in atmospheric greenhouse gases levels contribute to global 
Biogeosciences Discuss., https://doi.org/10.5194/bg-2018-112

Manuscript under review for journal Biogeosciences

Discussion started: 16 March 2018

(c) Author(s) 2018. CC BY 4.0 License.

warming with significant local and regional changes in precipitation regimes (IPCC, 2007). Such great changes in temperature and precipitation have a significant impact not only on nutrient element cycling in those regions where plant growth and development tend to be limited by nutrient availability (Hungate et al., 2003; Austin et al., 2004; Nelson et al., 2004), but also on soil nutrient availability and plant nutrient status (Vitousek, 2004; Yuan et al., 2006; Yuan and Chen, 2009a). Given that changes in these climatic factors can influence the N and P in green (Reich and Oleksyn, 2004; Wright et al., 2004; Chen et al., 2013) and senesced leaves (Read et al., 2003; Parton et al., 2007; Ge et al., 2016), the NRE and PRE may also change with these climatic factors. It is therefore imperative to acquire more information about the NRE and PRE responses to global environmental factors and to predict these responses in light of future climate changes (Gordon and Jackson, 2000; De Frenne et al., 2013; Brant and Chen, 2015).

Currently, it is well known that the $\mathrm{N}$ and $\mathrm{P}$ contents of leaves also exhibit distinct biogeographic patterns (Han et al., 2005; Niklas et al., 2007; Yuan and Chen., 2009b; Vergutz et al., 2012; Kang et al., 2010; Ge et al., 2016). Indeed, there is sufficient evidence to conclude that NRE and PRE also differ in response to ecological variables such as mean annual temperature and rainfall (Richardson et al., 2005; Yuan and Chen, 2009a; Vergutz et al., 2012; Tang et al., 2013). In particular, most meta-analyses at a global and regional level have shown that NRE and PRE are related to latitude, mean annual temperature (MAT), and mean annual precipitation (MAP)(Yuan and Chen, 2009a; Vergutz et al., 2012; Tang et al., 2013). For example, Yuan and Chen (2009a) 
Biogeosciences Discuss., https://doi.org/10.5194/bg-2018-112

Manuscript under review for journal Biogeosciences

Discussion started: 16 March 2018

(c) Author(s) 2018. CC BY 4.0 License.

found that within different plant functional groups (trees, shrubs, broadleaf species, and conifers), NRE and PRE have opposite trends with respect to MAT and MAP and with latitude, i.e., NRE decreases with increasing MAT and MAP but increases with respect to latitude, whereas PRE increases with respect to MAT and MAP but decreases with latitude. These trends are consistent with the results reported by Tang et al., (2013) in Eastern China for woody plants. In contrast, Vergutz et al., (2012) reveal that both NRE and PRE decrease with MAT and MAP and increase with respect to latitude at a global level. Although great progress has been made on the relationships between NRE and PRE and ambient climatic factors at the local (Wright and Westoby, 2003; Tully et al., 2013; Zhao et al., 2017), regional (Tang et al., 2013; Kang et al., 2015; Sun et al., 2016) and global scales (Kobe et al., 2005; Yuan et al., 2009b; Vergutz et al., 2012), such mixed findings present an obstacle to modelling global biogeochemical cycling. In particular, most meta-analyses have reported global trends of nutrient resorption for woody plants, with little data pertaining to herbaceous plants (Vergutz et al., 2012). This gap in our knowledge is particularly important because perennial grasses also play a substantial role in a range of global-scale processes, including productivity and nutrient cycling and limitation, and an understanding nutrient-resorption characteristics of these species has significant global change implication (Hobbie, 1992; Knops et al., 2002; Zhou et al., 2006). Therefore, additional studies of herbaceous plants on the global scale are badly needed.

For this purpose, we assembled a global database from published studies to explore 
Biogeosciences Discuss., https://doi.org/10.5194/bg-2018-112

Manuscript under review for journal Biogeosciences

Discussion started: 16 March 2018

(c) Author(s) 2018. CC BY 4.0 License.

118 (1) variations in NRE and PRE across a diverse spectrum herbaceous species, and (2)

119 identify how NRE, PRE and N:P ratios of resorption efficiency (NRE:PRE) vary as a

function of latitude, MAT, and MAP. We also investigated whether there is a global

pattern of NRE, PRE and NRE:PRE with respect to latitude, MAT, and MAP and, if

so, whether it differed between different functional species groups (i.e., graminoids vs.

forbs and monocots vs. eudicots).

\section{Materials and Methods}

\section{$125 \quad 2.1$ Data collection}

126

A global meta-analysis was conducted using published data for NRE and PRE (see Appendix S1 in Supporting Information). To ensure data comparability, we used data from papers in which the authors specifically indicated that leaf litter samples came from newly fallen leaves that fell naturally or from freshly filled litter-traps. Further, we excluded data from leguminous plants (N-fixing species), plants grown under greenhouse conditions, and from fertilized plants. We used the Global Gazetteer Version 2.2 (http://www.fallingrain.com/world/) and WorldClim 1.4 database (http://www.worldclim.org/) to determine latitude, longitude, altitude, temperature and precipitation data (a global dataset with spatial resolution of $c .1 \mathrm{~km}^{2}$ ) if this information was missing in the original paper. In total, 521 observations were collected encompassing 248 herbaceous species from 55 studies. Across this global data set, sites ranged from 0 to $4756 \mathrm{~m}$ in altitude, from -9 to $27^{\circ} \mathrm{C}$ in MAT, and from 7.3 to $4000 \mathrm{~mm}^{-1}$ year $^{-1}$ in MAP. Accordingly, the dataset broadly covered most of the range of MAT and MAP occupied by the majority of herbaceous species and thus permitted a detailed global level of analysis not previously possible. 
Biogeosciences Discuss., https://doi.org/10.5194/bg-2018-112

Manuscript under review for journal Biogeosciences

Discussion started: 16 March 2018

(c) Author(s) 2018. CC BY 4.0 License.

\subsection{Data analysis}

The mean values of NRE and PRE between functional species groups (i.e., graminoids vs. forbs and monocots vs. eudicots) were assessed using one-way analysis of variance (ANOVA) and least-significant difference (LSD) post-hoc analyses when effects were significant. Data for NRE, PRE, and NRE:PRE ratios were $\log _{10}$-transformed before analysis in order to meet assumptions of normality and homogeneity of variances. Multiple regression analysis was used to identify the effects of latitude, MAT, and MAP on NRE, PRE and NRE:PRE. The combined effects of functional type, phylogeny (monocots versus eudicots), and MAT and MAP on NRE, PRE, and NRE:PRE were determined using analysis of variance. General linear model (GLM) was also used to examine if the responses of NRE, PRE, and NRE:PRE to MAT and MAP differed between different functional species groups. All statistical analyses were performed using $\mathrm{R}$ for Window version 3.1.0 statistical software (R Core Team 2014).

\section{Results}

For the pooled data, the mean NRE and PRE were $54.7 \%(n=521, \mathrm{SD}=0.73 \%)$ and 64.5\% $(n=360, \mathrm{SD}=0.79 \%)$, respectively. NRE and PRE differed significantly between the two functional groups. Forbs had lower NRE and PRE (52.8\% and 61.2\%) than graminoids $(57.3 \%$ and $68.4 \%)(P<0.05)$, whereas monocots had higher NRE and PRE (55.8\% and 67\%) than eudicots $(52.9 \%$ and $61.3 \%)(P<0.05)$ (Fig. 1).

NRE, PRE, and NRE:PRE manifested statistically significant trends with altitude, MAT, and MAP. For the pooled data, NRE, PRE, and NRE:PRE were positively correlated with latitude and negatively correlated with both MAT and MAP $(P<$ 
Biogeosciences Discuss., https://doi.org/10.5194/bg-2018-112

Manuscript under review for journal Biogeosciences

Discussion started: 16 March 2018

(c) Author(s) 2018. CC BY 4.0 License.

0.0001 ) (Table S1). Latitude, MAT, and MAP respectively accounted for $6 \%, 4 \%$, and $5 \%$ of the variation observed in NRE, $8 \%, 6 \%$, and $6 \%$ of variation observed in PRE, and $4 \%, 4 \%$ and $2 \%$ of variation observed in NRE:PRE. MAT, MAP, and latitude collectively explained $11-19 \%$ of the variation observed in NRE, PRE, and NRE:PRE (Table 1). Functional type and climatic data collectively explained 10\%, 16\% and 7\% of global variation observed in NRE, PRE, and NRE:PRE (Table 2).

Similar patterns of NRE, PRE, and NRE:PRE with respect to latitude, MAT, and MAP were observed for the two life-form groups (forbs vs. graminoids) and for the two phylogenetic groups (monocots vs. eudicots) (Fig. 2 and Fig. 3). Although there were differences between regression slopes between forbs and graminoids and between monocots and eudicots (Table 3), the responses of NRE, PRE, and NRE:PRE to MAT and MAP were qualitatively similar.

\section{Discussion}

\subsection{Functional traits and differences in NRE and PRE at the global level}

We evaluated leaf NRE and PRE in herbaceous species using a global dataset. The mean values of NRE and PRE across all the herbaceous species are $54.7 \%$ and $64.5 \%$, respectively. These values are only slightly higher than values reported by Aerts, (1996) based on a comparatively few data for only herbaceous species at a global scale (i.e., 50\% and 57\%, respectively), but lower than values reported by Jiang et al., (2012) for 18 herbaceous species in the Qinghai-Tibetan Plateau (i.e., 65.2\% and $67.4 \%$ ). However, these values are markedly higher than those reported for woody plants by Yuan et al., (2009a) (i.e., 47\% and 54\%, respectively, at a global level) or by Tang et al., (2013) (i.e., 49\% and 51\%, respectively, at the regional scale). Nutrient 
Biogeosciences Discuss., https://doi.org/10.5194/bg-2018-112

Manuscript under review for journal Biogeosciences

Discussion started: 16 March 2018

(c) Author(s) 2018. CC BY 4.0 License.

resorption efficiency of herbaceous species show obviously higher values than the

values of woody species. The relatively higher nutrient resorption efficiency has been interpreted to indicate that non-woody species are more well adapted to nutrient stress through high internal $\mathrm{N}$ and $\mathrm{P}$ recycling (Norris and Reich, 2009; Freschet et al., 2010).

Additionally, NRE and PRE differ significantly between graminoids and forbs at a global scale. Both NRE and PRE are significantly higher in the former functional type compared to forbs (Fig. 1). This finding is consistent with previous observations (Aerts, 1996; Jiang et al., 2012) and has been interpeted to indicate that graminoids have a competitive advantage over forbs, which provides additional evidence that productivity, foliar nutrient allocation, and leaf biomass may lead to the higher nutrient reabsorption in graminoids compared to forbs (Aerts and Berendse, 1989). Likewise, monocots have higher NRE and PRE compared to eudicots (Fig. 1). However, in this context, it is important to note that the data for monocots are biased because approximately one half of all of the monocots in our data set are graminoids, further investigations are warranted to be conclusive.

\subsection{Climatic variations in NRE and PRE at the global level}

This study presents the first global-scale analyses on how nutrient resorption of $\mathrm{N}$ and P differentially vary with environmental variables across a broad spectrum of herbaceous species. Based on this worldwide level of analysis, both NRE and PRE increase with latitude and decrease with MAT and MAP across all herbaceous species. Plants from tropical habitats (higher temperatures) have lower NRE and PRE, whereas plants from high-latitude habitats (lower-temperatures) have higher NRE and 
Biogeosciences Discuss., https://doi.org/10.5194/bg-2018-112

Manuscript under review for journal Biogeosciences

Discussion started: 16 March 2018

(c) Author(s) 2018. CC BY 4.0 License.

PRE. These trends hold true for each of the two functional types as well as when the data are pooled (Fig. 2 and Fig. 3).

In terms of NRE, the trends reported here are similar to those of Yuan and Chen, (2009a) and Tang et al., (2013) who found that NRE increased with increasing latitude but decreased with increasing MAT and MAP across woody species. Collectively, these findings support the idea that plants growing at low latitudes, or in areas with high precipitation or temperature are on average more P-limited and would be expected to have lower NRE (Austin and Vitousek, 1998; Aerts and Chapin, 1999; Sterner and Elser, 2002; Reich and Oleksyn, 2004; Santiago et al., 2005). Our results are also supported by findings from common-garden experiments (Oyarzabal et al., 2007), which report a negative relationship between NRE and both MAT and MAP. However, the trends we observed differ from those reported by Aerts et al., (2007), who found that controlled temperature and precipitation treatment had little or no effect on NRE in a high-latitude subarctic peatland. This inconsistency can be attributed to the fact that Aerts et al., (2007) used short-term temperature and precipitation manipulations on a single plant community, whereas our study examined different plant communities across large environmental gradients.

Regarding the NRE pattern reported here, our results are in accordance with the global patterns observed across species by Vergutz et al., (2012) and the regional patterns observed for a single species by Sun et al., (2015). In turn, it is the opposite of that reported by Yuan and Chen, (2009a) and by Tang et al., (2013), who observed that PRE is negatively correlated with latitude and positively correlated with MAT 
Biogeosciences Discuss., https://doi.org/10.5194/bg-2018-112

Manuscript under review for journal Biogeosciences

Discussion started: 16 March 2018

(c) Author(s) 2018. CC BY 4.0 License.

and MAP for woody species. The opposite patterns of PRE in woody and herbaceous

species could reflect different plant growth form conservation strategies in responses

to climatic differences. It is generally agreed that NRE and PRE patterns are

influenced significantly by soil nutrient availability, which can affect plant

conservation strategies including nutrient resorption (Oleksyn et al., 2003, Yuan et al.,

2005). Previous studies have shown that the effects of temperature and precipitation and Chen, 2015). However, the climatic patterns of PRE reported here do not manifest this trend. We attribute this to the considerable heterogeneity in tropical soil nutrient conditions and availability (Richter and Babbar, 1991; Reed et al., 2012) that vary across large temporal and spatial scales (Hedin et al., 2009). Unfortunately, data recording this variability are currently unavailable. Further studies are required to resolve this apparent paradox.

The NRE and PRE reported here may also reflect the nutrient conservation strategies of herbaceous species growing at high latitudes with low MAT and MAP. Cold temperatures and drought are known to inhibit the nutrient uptake of roots and

251 thus constrain the metabolic activity of herbaceous plants (Sun et al., 2015). 
Biogeosciences Discuss., https://doi.org/10.5194/bg-2018-112

Manuscript under review for journal Biogeosciences

Discussion started: 16 March 2018

(c) Author(s) 2018. CC BY 4.0 License.

contents, and an accelerated life history, Adler et al., 2014) that can collectively

255 reduce $\mathrm{N}$ and $\mathrm{P}$ acquisition by roots and their associated ectomycorrhiza (Lambers et

al., 2008). In turn, the relatively high degradation capacity of nutrient (Tsujii et al.,

2017) would encourage high NRE and PRE as an adaptation.

\subsection{Climatic variations in NRE:PRE at the global level}

The patterns of NRE:PRE reported here differs from those reported by Sun et al.,

260

261

262 (2015), who found that NRE : PRE has no significant correlation with either latitude or MAP and only a very weak statistical relationship with MAT. The difference between the findings of Sun et al., (2015) and ours may be explained by the fact that Sun et al., (2015) focused on only a single species at a regional scale, whereas our results reflect interspecific variation at a global scale. In contrast, our findings are consistent with the global patterns observed for woody species by Reed et al., (2012) and by Han et al., (2013), who report that NRE:PRE increases with latitude and decreases with MAT and MAP. The NRE:PRE pattern we observe provides indirect evidence indicating that plants growing in the tropics with higher MAT and MAP are more frequently $\mathrm{P}$ limited, whereas plants growing in higher latitudes with lower MAT and MAP are often N limited (Austin and Vitousek, 1998; Sterner and Elser, 2002; Reich and Oleksyn, 2004). Because nutrient availability can strongly influence nutrient resorption (Pugnaire and Chapin, 1993). NRE is generally expected to be higher (and PRE lower) at higher latitude compared to the tropics. However, the PRE pattern reported here is not consistent with this expectation. As noted, we speculate that the acclimation responses of herbaceous species to soil nutrient availability and the heterogeneity of tropical soil nutrient content help to explain this apparent 
Biogeosciences Discuss., https://doi.org/10.5194/bg-2018-112

Manuscript under review for journal Biogeosciences

Discussion started: 16 March 2018

(c) Author(s) 2018. CC BY 4.0 License.

contradiction.

\section{Conclusion}

Our analyses indicate that, when viewed at a worldwide level, more than half of all

leaf $\mathrm{N}$ and $\mathrm{P}$ is resorbed during senescence in herbaceous species at a global level.

Nevertheless, $\mathrm{N}$ and $\mathrm{P}$ resorption efficiencies and their ratios manifest discernable

These patterns hold for two functional types (graminoids and forbs) and for phylogenetic groups (monocots and eudicots), indicating that they are sensitive to

functional or phylogenetic traits. These trends can inform attempts to model potential

changes in ecosystem dynamics in response to changing climate and attempts to model biogeochemical cycling at a global scale.

\section{Funding}

This study was supported by grants from Chinese National Basic Research Program

(2014CB954203), the National Natural Science Foundation of China (31601782,

\section{Author contributions}

The authors declare that they have no conflict of interest.

\section{Competing interests}

The authors declare that they have no conflict of interest.

\section{Acknowledgments}

We are grateful to Changcheng Liu and Ke Guo from the Institute of Botany, Chinese 
Biogeosciences Discuss., https://doi.org/10.5194/bg-2018-112

Manuscript under review for journal Biogeosciences

Discussion started: 16 March 2018

(c) Author(s) 2018. CC BY 4.0 License.

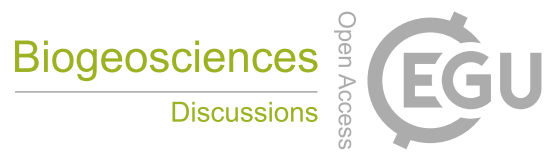

(c) (i)

304 Academy of Sciences, Yulin Li from the Northwest Institute of Eco-Environment and

305 Resources, Chinese Academy of Sciences, Lei Li from the Xinjiang Institute of

306 Ecology and Geography, Chinese Academy of Sciences and Rob Jackson, from the

307 Duke University for access to their raw data.

308

309

310

311

312

313

314

315

316

317

318

319

320

321

322

323

324

325 
Biogeosciences Discuss., https://doi.org/10.5194/bg-2018-112

Manuscript under review for journal Biogeosciences

Discussion started: 16 March 2018

(c) Author(s) 2018. CC BY 4.0 License.

\section{References}

Adler, P. B., Salguero-Gomez, R., Compagnoni, A., Hsu. J. S., Ray-Mukherjee, J., Mbeau-Ache, C., Franco, M.: Functional traits explain variation in plant life history strategies, Proc. Natl Acad. Sci. USA., 111, 740-745, 2014.

Aerts, R.: Nutrient Resorption from Senescing Leaves of Perennials: Are there General Patterns?, J. Ecol., 84. 597-608, 1996.

Aerts, R., and Berendse, F.: Above-Ground Nutrient Turnover and Net Primary Production of an Evergreen and a Deciduous Species in a Heathland Ecosystem, J. Ecol., 77, 343-356, 1989.

Aerts, R., and Chapin, F. S.: The Mineral Nutrition of Wild Plants Revisited: A Re-evaluation of Processes and Patterns, Adv. Ecol. Res., 30, 1-67, 1999.

Aerts, R., Cornelissen, J. H., van Logtestijn, R. S., Callaghan, T. V.: Climate change has only a minor impact on nutrient resorption parameters in a high-latitude peatland, Oecologia., 151, 132-139, 2007.

Austin, A. T., and Vitousek, P. M.: Nutrient dynamics on a precipitation gradient in Hawai'I, Oecologia., 113, 519-529, 1998.

Austin, A. T.: Water pulses and biogeochemical cycles in arid and semiarid ecosystems, Oecologia., 141, 221-235, 2004.

Berg, B., and McClaugherty, C.: Plant litter: decomposition, humus formation, carbon sequestration, Springer Press, 2008.

Brant, A. N., and Chen, H. Y. H.: Patterns and Mechanisms of Nutrient Resorption in Plants, Crit. Rev. Plant. Sci., 34, 471-486, 2015. 
Biogeosciences Discuss., https://doi.org/10.5194/bg-2018-112

Manuscript under review for journal Biogeosciences

Discussion started: 16 March 2018

(c) Author(s) 2018. CC BY 4.0 License.

Chapin, F. S.: The mineral nutrition of wild plants, Annu. Rev. Ecol. Syst., 11, $233-260,1980$.

Chapin, F. S., Matson, P. A., Vitousek, P. M.: Principle of terrestrial ecosystem ecology, Springer. Press, 2011.

Chen, Y. H., Han, W. X., Tang, L. Y., Tang, Z. Y., Fang, J. Y.: Leaf nitrogen and phosphorus concentrations of woody plants differ in responses to climate, soil and plant growth form, Ecography., 36, 178-184, 2013.

De Frenne, P., Graae, B. J., Rodriguez-Sanchez, F., Kolb, A., Chabrerie, O., Decocq, G., De Kort, H., De Schrijver, A., Diekmann, M., Eriksson, O., Gruwez, R., Hermy, M., Lenoir, J., Plue, J., Commes, D. A., Verheyen, K.: Latitudinal gradients as natural laboratories ot infer species' responses to temperature, J. Ecol., 101, 784-795, 2013.

Freschet, G. T., Cornelissen, J. H. C., van Logtestijn, R. S. P., Aerts, R.: Substantial nutrient resroption from leaves, stems and roots in a subarctic flora: what is the link with other resource economics traits?, New. Phytol., 186, 879-889, 2010.

Ge, J. L., Wang, Y., Xu, W. T., Xie, Z. Q.: Latitudinal patterns and climatic drivers of leaf litter multiple nutrients in chinese broad-leaved tree species: does leaf habit matter?, Ecosystems., 1-13, 2016.

Gordon, W. S., and Jackson, R. B.: Nutrient concentrations in fine roots, Ecology., 81, $275-280,2000$.

Güsewell, S.: N:P ratios in terrestrial plants: variation and functional significance, 
Biogeosciences Discuss., https://doi.org/10.5194/bg-2018-112

Manuscript under review for journal Biogeosciences

Discussion started: 16 March 2018

(c) Author(s) 2018. CC BY 4.0 License.

371 Han, W. X., Fang, J. Y., Guo, D. L., Zhang, Y.: Leaf nitrogen and phosphorus stoichiometry across 753 terrestrial plant species in China, New. Phytol., 168, $377-385,2005$.

Han, W. X., Tang, L. Y., Chen, Y. H., Fang, J. Y.: Relationship between the relative limitation and resorption efficiency of nitrogen vs phosphorus in woody plants, PLoS. ONE., 8, e83366, 2013.

Hedin, L. O., Brookshire, E. N. J., Menge, D. N. L., Barron, A. R.: The nitrogen paradox in tropical forest ecosystems, Ann. Rev. Ecol. Evol. Syst., 40, $613-635,2009$.

Hobbie, S. E.: Effect of plant species on nutrient cycling, Trends. Ecol. Evol., 7, 336-339, 1992.

Hungate, B. A., Dukes, J. S., Shaw, M. R., Luo, Y. Q., Field, C. B.: Nitrogen and climate change, Science., 302, 1512-1513, 2003.

IPCC: Climate change 2007: the physical science basis of climate chang, Working Group I report, fourth assessment report on climate change, International Panel on Climate Change, Cambridge Univ. Press, 2007.

Jiang, C. M. Yu, G. R., Li, Y. N., Cao, G. M., Yang, Z. P., Sheng, W. P., Yu, W. T.: Nutrient resorption of coexistence species in alpine meadow of the Qinghai-Tibetan Plateau explains plant adaptation to nutrient-poor environment, Ecol. Engin., 44, 1-9, 2012.

Kang, H. Z., Xin, Z. J., Berg, B., Burgess, P. J., Liu, Q. L., Liu, Z. C., Li, Z. H., Liu, C. 
Biogeosciences Discuss., https://doi.org/10.5194/bg-2018-112

Manuscript under review for journal Biogeosciences

Discussion started: 16 March 2018

(c) Author(s) 2018. CC BY 4.0 License.

J.: Global pattern of leaf litter nitrogen and phosphorus in woody plants, Ann. For. Sci., 67: 811, 2010.

Killingbeck, K. T.: The terminological jungle revisited-making a case for use of the term resorption, Oikos., 46, 263-264, 1986.

Killingbeck, K. T.: Nutrients in Senesced Leaves: Keys to the Search for Potential Resorption and Resorption Proficiency, Ecology, 77, 1716-1727, 1996.

Knops, J. M. H., Bradley, K. L., Wedin, D. A.: Mechanisms of plant species impact on ecosystem nutrient cycling, Ecol. Lett., 3, 454-466, 2002.

Kobe, R. K., Lepczyk, C. A., Iyer, M.: Resorption efficiency decreases with increasing green leaf nutrients in a global data set, Ecology., 86, 2780-2792, 2005.

Lambers, H., Raven, J. A., Shaver, G. R., Smith, S. E.: Plant nutrient acquisition stragegies change with soil age, Trends. Ecol. Evol., 23, 95-103, 2008.

Nelson, D. M., Hu, F. S., Tian, J., Stefanova, I., Brown, T. A.: Response of C3 and C4 plants to middle-Holocene climatic variation near the prairie-forest ecotone of Minnesota, Proc. Natl Acad. Sci. USA., 101, 562-567, 2004.

Niklas, K. J., Cobb, E. D., Niinemets, Ü., Reich, P. B., Sellin, A., Shipley, B., Wright, I. J.: "Diminishing returns" in the scaling of functional leaf traits across and within species groups, Proc. Natl Acad. Sci. USA., 104, 8891-8896, 2007.

Norris, M. D., and Reich, P. B.: Modest enhancement of nitrogen conservation via retranslocation in response to gradients in $\mathrm{N}$ supply and leaf $\mathrm{N}$ status, Plant. Soil., 316, 193-204, 2009. 
Biogeosciences Discuss., https://doi.org/10.5194/bg-2018-112

Manuscript under review for journal Biogeosciences

Discussion started: 16 March 2018

(c) Author(s) 2018. CC BY 4.0 License.

Oleksyn, J., Reich, P. B., Zytkowiak, R., Karolewski, P., Tjoelker, M. G.: Nutrient conservation increases with latitude of origin in European Pinus sylvestris populations, Oecologia., 136, 220-235, 2003.

Oyarzabal, M., Paruelo, J. M., del Pino, F., Oesterheld, M., Lauenroth, W. K.: Trait differences between grass species along a climatic gradient in South and North America, J. Veget. Sci., 19, 183-192, 2007.

Parton, W., Silver, W. L., Burke, I. C., Grassens, L., Harmon, M. E., Currie, W. S., King, J. Y., Adair, E. C., Brandt, L. A., Hart, S. C., Fasth, B.: Global-scale similarities in nitrogen release patterns during long-term decomposition, Science, 315, 361-364, 2007.

Pugnaire, F. I., and Chapin, F. S.: Controls over nutrient resorption from leaves of evergreen Mediterranean species, Ecology., 74, 124-129, 1993.

R Core Team: R: a language and environment for statistical computing, R Foundation for Statistical Computing, Vienna, Austria. http://www.R-project.org, 2014.

Read, L., and Lawrence, D.: Litter Nutrient Dynamics During Succession in Dry Tropical Forests of the Yucatan: Regional and Seasonal Effects, Ecosystems., 6, 747-761, 2003.

Reed, S. C., Townsend, A. R., Davidson, E. A., Cleveland, C. C.: Stoichiometric patterns in foliar nutrient resorption acorss multiple scales, New. Phytol., 196, 173-180, 2012.

Reich, P. B., and Oleksyn, J.: Global patterns of plant leaf $\mathrm{N}$ and $\mathrm{P}$ in relation to temperature and latitude. Proc. Natl Acad. Sci. USA., 101, 11001-11006, 
Biogeosciences Discuss., https://doi.org/10.5194/bg-2018-112

Manuscript under review for journal Biogeosciences

Discussion started: 16 March 2018

(c) Author(s) 2018. CC BY 4.0 License.

2004.

437 Richardson, S. J., Allen, R. B., Doherty, J. E.: Shifts in leaf N:P ratio during resorption reflect soil $\mathrm{P}$ in temperate rainforest, Funct. Ecology, 22, 738-745, 2008.

440

441

442

443

444

445

446

447

448

449

450

451

452

453

454

455

456

457

Richardson, S. J., Peltzer, D. A., Allen, R. B., McGlone, M.: Resorption proficiency along a chronosequence: responses among communities and within species, Ecology, 86, 20-25, 2005.

Richter, D. D., and Babbar, L. I.: Soil Diversity in the Tropics, Adv. Ecol. Res., 21, 315-389, 1991.

Santiago, L. S., Schuur, E. A. G., Silvera, K.: Nutrient cycling and plant-soil feedbacks along a precipitation gradient in lowland Panama, J. Tropical. Ecol., 21, 461-470, 2005.

Sterner, R. W., and Elser, J. J.: Ecological stoichiometry: the biology of elements from molecules to the biosphere, Princeton Univ. Press, 2002.

Sun, X., Kang, H. Z., Chen, H. Y. H., Berg, B., Bartels, S. F., Liu, C. J.: Biogeographic patterns of nutrient resorption from Quercus variabilis Blume leaves across China, Plant. Biol, 8, 505, 2016.

Tang, L. Y., Han, W. X., Chen, Y. H., Fang, J. Y.: Resorption proficiency and efficiency of leaf nutrients in woody plants in eastern China, J. Plant. Ecol, 6, $408-417,2013$.

Tsujii, Y., Onoda, Y., Kitayama, K.: Phosphorus and nitrogen resorption from different chemical fractions in senescing leaves of tropical tree species on Mount 
Biogeosciences Discuss., https://doi.org/10.5194/bg-2018-112

Manuscript under review for journal Biogeosciences

Discussion started: 16 March 2018

(c) Author(s) 2018. CC BY 4.0 License.

Kinabalu, Borneo, Oecologia., 185, 171-180, 2017.

Tully, K. L., Wood, T. E., Schwantes, A. M., Lawrence, D.: Soil nutrient availability and reproductive effort drive patterns in nutrient resorption in Pentaclethra macroloba, Ecology., 94, 930-940, 2013.

Vergutz, L., Manzoni, S., Porporato, A., Novais, R. F., Jackson, R. B.: Global resorption efficiencies and concentrations of carbon and nutrients in leaves of terrestrial plants, Ecol. Monogr., 82, 205-220, 2012.

Vitousek, P. M.: Litterfall, Nutrient Cycling, and Nutrient Limitation in Tropical Forests. Ecology., 65, 285-298, 1984.

Vitousek, P. M.: Nutrient cycling and limitation: Hawai'i as a model system, Princeton Univ. Press, 2004.

Wright, I. J., and Westoby, M.: Nutrient concentration, resorption and lifespan: leaf traits of Australian sclerophyll species, Funct. Ecol., 17, 10-19, 2003.

Wright, I. J., Reich, P. B., Westoby, M., Ackerly, D. D., Baruch, Z., Bongers, F., Cavender-Bares, J., Chapin, T., Cornelissen, J. H. C., Diemer, M., Flexas, J., Garnier, E., Groom, P. K., Gulias, J., Hikosaka, K., Lamont, B. B., Lee, T., Lee, W., Lusk, C., Midgley, J. J., Navas, M., Niinemets, Ü., Oleksyn, J., Osada, N., Poorter, H., Poot, P., Prior, L., Pyankov, V. I., Roumet, C., Thomas, S. C., Tjoelker, M. G., Veneklaas, E. J., Villar R.: 2004. The worldwide leaf economics spectrum. Nature. - 428: 821-827.

Yuan, Z. Y., and Chen, H. Y. H.: Global-scale patterns of nutrient resorption associated with latitude, temperature and precipitation. Global Ecol. Biogeogr., 
Biogeosciences Discuss., https://doi.org/10.5194/bg-2018-112

Manuscript under review for journal Biogeosciences

Discussion started: 16 March 2018

(c) Author(s) 2018. CC BY 4.0 License.

18, 11-18, 2009a.

Yuan, Z. Y., and Chen, H. Y. H.: Global trends in senesced-leaf nitrogen and phosphorus. Global Ecol. Biogeogr., 18, 532-542, $2009 \mathrm{~b}$.

Yuan, Z. Y., and Chen, H. Y. H.: Negative effects of fertilization on plant nutrient resorption, Ecology., 96, 373-380, 2015.

Yuan, Z. Y., Li, L. H., Han, X. G., Huang, J. H., Jiang, G. M., Wan, S. Q., Zhang, W. H., Chen, Q. S.: Nitrogen resorption from senescing leaves in 28 plant species in a semi-arid region of northern China, J. Arid. Envir., 63, 191-202, 2005.

Yuan, Z. Y., Li, L. H., Han, X. G., Chen, S. P., Wang, Z. W., Chen, Q. S., Bai, W. M.: Nitrogen response efficiency increased monotonically with decreasing soil resource availability: a case study from a semiarid grassland in northern China, Oecologia., 148, 564-572, 2006.

Zhang, Y. J., Yang, Q. Y., Lee, D. W., Goldstein, G., Cao, K. F.: Extended leaf senescence promotes carbon gain and nutrient resorption: importance of maintaining winter photosynthesis in subtropical forests, Oecologia., 173, $721-730,2013$.

Zhao, G. S., Shi, P. L., Wu, J. S., Xiong, D. P., Zong, N., Zhang, X. Z.: Foliar nutrient resorption patterns of four functional plants along a precipitation gradient on the Tietan Changtang Plateau, Ecol. Evol., 7, 7201-7212, 2017.

Zhou, Z., Sun, Q. J., Huang, J., Gao, Y., Han, X.: Land-use affects the relationship between species diversity and productivity at the local scale in a semi-arid steppe ecosystem, Funct. Ecol., 20, 753-762, 2006. 
Biogeosciences Discuss., https://doi.org/10.5194/bg-2018-112

Manuscript under review for journal Biogeosciences

Discussion started: 16 March 2018

(c) Author(s) 2018. CC BY 4.0 License.

503 Figure Legends

504 Fig. 1. Mean nitrogen resorption efficiency (NRE) and phosphorus resorption

505 efficiency (PRE) for functional types (forbs, F versus graminoids, G) and

506 phylogenetic groups (monocots, $M$ versus eudicots, E). Different letters (a and b)

507 indicate significant differences at the 0.05 level. Error bas are standard errors. The

508 number of observations is given within each bar.

509 Fig. 2. Nutrient resorption efficiencies (NRE and PRE) and nutrient resorption

510 efficiency ratio (NRE:PRE) in relation to latitude $\left({ }^{\circ}\right)$, mean annual temperature

511 (MAT, ${ }^{\circ} \mathrm{C}$ ), and mean annual precipitation (MAP, mm). Red and blue circles represent

512 data points for graminoids and forbs, respectively. The coefficients of determination

$513\left(r^{2}\right)$ and $P$ are provided in each panel for graminoids (the first line) and forbs (the

514 second line).

515 Fig. 3. Nutrient resorption efficiencies (NRE and PRE) and nutrient resorption

516 efficiency ratio (NRE:PRE) in relation to latitude $\left({ }^{\circ}\right)$, mean annual temperature

517 (MAT, ${ }^{\circ} \mathrm{C}$ ), and mean annual precipitation (MAP, mm). Red and blue circles represent

518 data points for monocots and eudicots, respectively. The coefficients of determination

$519\left(r^{2}\right)$ and $P$ are shown in each panel for eudicots (the first line) and monocots (the

520 second line). 
Biogeosciences Discuss., https://doi.org/10.5194/bg-2018-112

Manuscript under review for journal Biogeosciences

Discussion started: 16 March 2018

(c) Author(s) 2018. CC BY 4.0 License.

528 Table 1 Multiple regression analyses of nitrogen resorption efficiency (NRE),

529 phosphorus resorption efficiency (PRE), and their ratio (NRE:PRE) in relation to

530 latitude, mean annual temperature (MAT, ${ }^{\circ} \mathrm{C}$ ) and mean annual precipitation (MAP,

$531 \mathrm{~mm})$.

532

\begin{tabular}{llllllll}
\hline Trait & $n$ & $R^{2}$ & Latitude $\boldsymbol{F}$ & MAT $F$ & MAP $F$ & MAT $\times$ MAP $F$ & Latitude $\times$ MAT $\times$ MAP $F$ \\
\hline NRE & 521 & 0.106 & $42.22^{* * *}$ & $1.28^{\text {ns }}$ & $3.15^{*}$ & $0.33^{\text {ns }}$ & $4.46^{*}$ \\
PRE & 360 & 0.189 & $39.49^{* * *}$ & $1.63^{\text {ns }}$ & $0.25^{\text {ns }}$ & $10.86^{* *}$ & $26.60^{* * *}$ \\
NRE:PRE & 357 & 0.124 & $11.92^{* * *}$ & $0.96^{\text {ns }}$ & $4.00^{*}$ & $2.07^{\text {ns }}$ & $0.01^{\text {ns }}$ \\
\hline
\end{tabular}

$533 n$ is sample number. $F$ ratios and significance are shown for each of the dependent variables (ns, $P>0.05 ;{ }^{*} P<$

$\left.5340.05 ;{ }^{* *} P<0.01 ;{ }^{* * *} P<0.001\right)$.

535

536

537

538

539

540

541

542

543

544

545

546

547 
Biogeosciences Discuss., https://doi.org/10.5194/bg-2018-112

Manuscript under review for journal Biogeosciences

Discussion started: 16 March 2018

(c) Author(s) 2018. CC BY 4.0 License.

554 Table 2 Results of general linear models of nitrogen resorption efficiency (NRE),

555 phosphorus resorption efficiency (PRE), and their ratio (NRE:PRE) in relation to

556 functional type, latitude, mean annual temperature (MAT, ${ }^{\circ} \mathrm{C}$ ), and mean annual

557 precipitation (MAP, $\mathrm{mm}$ ).

\begin{tabular}{|c|c|c|c|c|c|c|c|}
\hline Trait & $n$ & $R^{2}$ & Phylogeny $\boldsymbol{F}$ & Life-form $F$ & Latitude $F$ & MAT $F$ & MAP $F$ \\
\hline NRE & 521 & 0.100 & $5.48^{*}$ & $5.10^{* * *}$ & $26.67^{* * *}$ & $0.95^{\mathrm{ns}}$ & $3.61^{*}$ \\
\hline PRE & 360 & 0.161 & $0.21^{\mathrm{ns}}$ & $8.50^{* * *}$ & $30.92^{* * *}$ & $1.84^{\mathrm{ns}}$ & $0.37^{\mathrm{ns}}$ \\
\hline NRE:PRE & 357 & 0.073 & $3.73^{*}$ & $2.12^{*}$ & $10.43^{* *}$ & $1.16^{\mathrm{ns}}$ & $3.70^{*}$ \\
\hline
\end{tabular}

560

561

562

563

564

565

566

567

568

569 
Biogeosciences Discuss., https://doi.org/10.5194/bg-2018-112

Manuscript under review for journal Biogeosciences

Discussion started: 16 March 2018

(c) Author(s) 2018. CC BY 4.0 License.

574 Table 3 Results of general linear models ( $F$-values for model terms and model $\left.R^{2}\right)$ of

578 precipitation (MAP) as continuous variables.

579

580

581

582

583

584

585

586

587

588

589

590

591

592

593

594

595

596

597

598

599

600

601

602

603

604

605

606

607

608

\begin{tabular}{lccc}
\hline Trait & NRE & PRE & NRE:PRE \\
\hline FG & $3.45^{* *}$ & $6.13^{* * *}$ & $2.71^{*}$ \\
MAT & $22.46^{* * *}$ & $31.92^{* * *}$ & $10.27^{* *}$ \\
MAP & $12.01^{* * *}$ & $1.92^{\mathrm{ns}}$ & $2.08^{\mathrm{ns}}$ \\
MAT $\times$ MAP & $1.20^{\mathrm{ns}}$ & $12.19^{* * *}$ & $1.85^{\mathrm{ns}}$ \\
FG $\times$ MAT & $3.99^{* *}$ & $0.75^{\mathrm{ns}}$ & $1.66^{\mathrm{ns}}$ \\
FG $\times$ MAP & $2.13^{\mathrm{ns}}$ & $3.07^{*}$ & $2.18^{\mathrm{ns}}$ \\
FG $\times$ MAT $\times$ MAP & $0.35^{\mathrm{ns}}$ & $5.62^{* *}$ & $3.57^{*}$ \\
Model $R^{2}$ & 0.12 & 0.21 & 0.11 \\
ME & $6.38^{*}$ & $20.75^{* * *}$ & $5.54^{*}$ \\
MAT & $22.27^{* * *}$ & $33.01^{* * *}$ & $10.00^{* *}$ \\
MAP & $11.90^{* * *}$ & $1.98^{\mathrm{ns}}$ & $2.03^{\mathrm{ns}}$ \\
MAT $\times$ MAP & 0.61 & $9.27^{* *}$ & $1.35^{\mathrm{ns}}$ \\
ME $\times$ MAT & $6.49^{*}$ & $2.50^{\mathrm{ns}}$ & $3.72^{*}$ \\
ME $\times$ MAP & $4.79^{*}$ & $13.37^{* * *}$ & $0.92^{\mathrm{ns}}$ \\
ME $\times$ MAT $\times$ MAP & $2.45^{\text {ns }}$ & $19.22^{* * *}$ & $1.76^{\mathrm{ns}}$ \\
Model $R^{2}$ & 0.10 & 0.22 & 0.08 \\
\hline
\end{tabular}

ns, $P>0.05 ;{ }^{*} P<0.05 ;{ }^{* *} P<0.01 ;{ }^{* * *} P<0.001$ 
Biogeosciences Discuss., https://doi.org/10.5194/bg-2018-112

Manuscript under review for journal Biogeosciences

Discussion started: 16 March 2018

(c) Author(s) 2018. CC BY 4.0 License.

Fig. 1

612

613

614
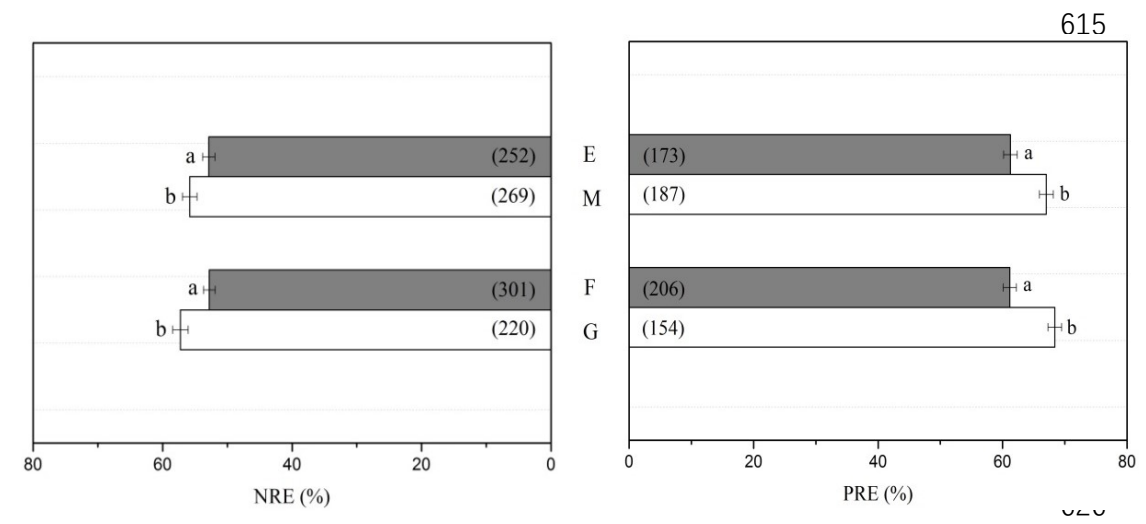
Biogeosciences Discuss., https://doi.org/10.5194/bg-2018-112

Manuscript under review for journal Biogeosciences

Discussion started: 16 March 2018

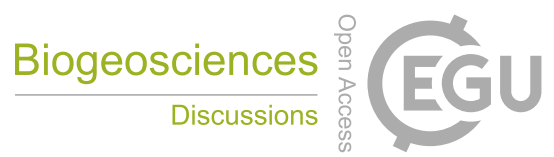

(c) Author(s) 2018. CC BY 4.0 License.

(c) $\underset{\mathrm{Br}}{\mathrm{Br}}$

Fig. 2

657

658
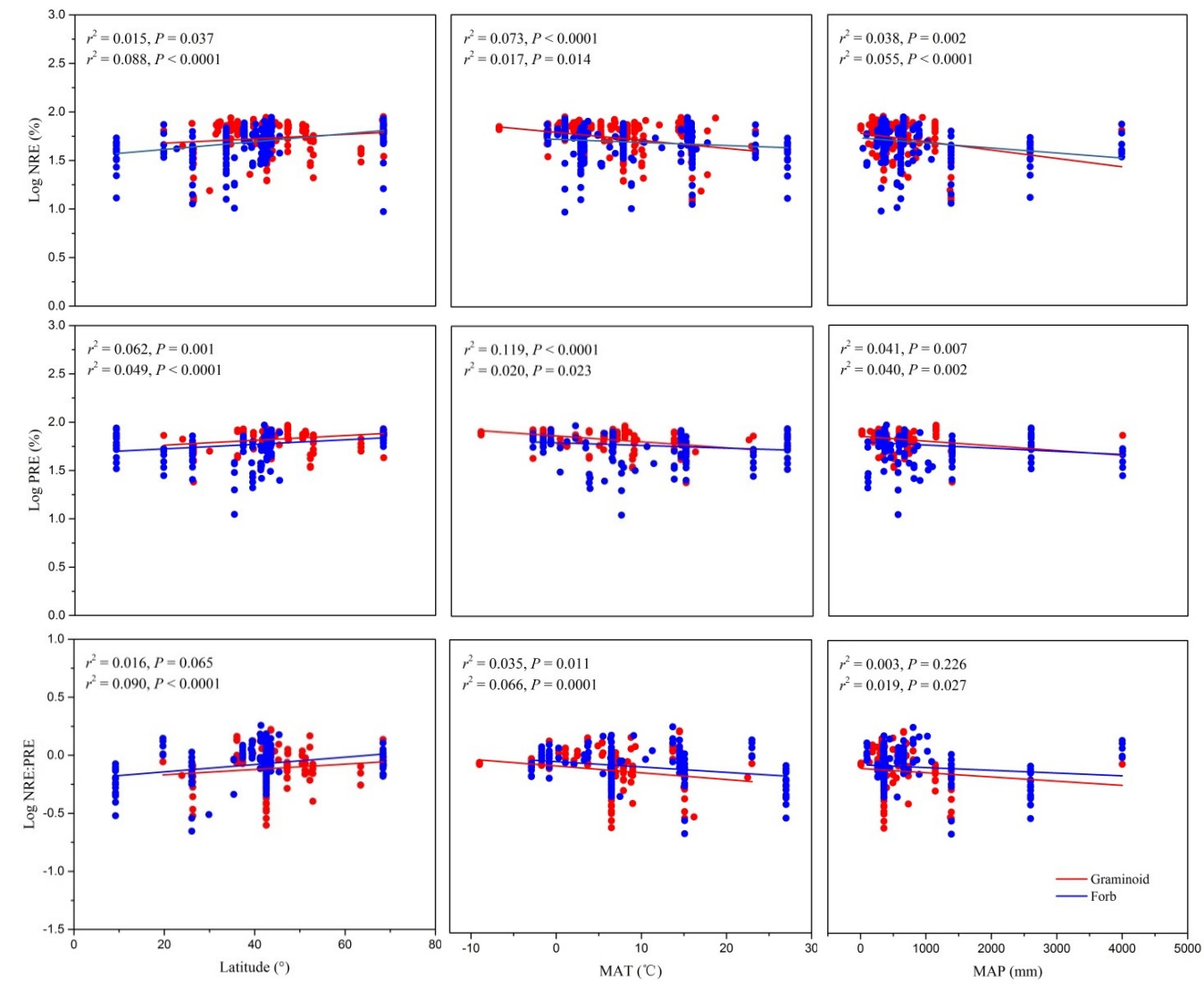
Biogeosciences Discuss., https://doi.org/10.5194/bg-2018-112

Manuscript under review for journal Biogeosciences

Discussion started: 16 March 2018

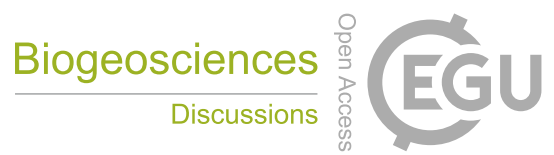

(c) Author(s) 2018. CC BY 4.0 License.

\section{(c) (1)}

Fig. 3

678
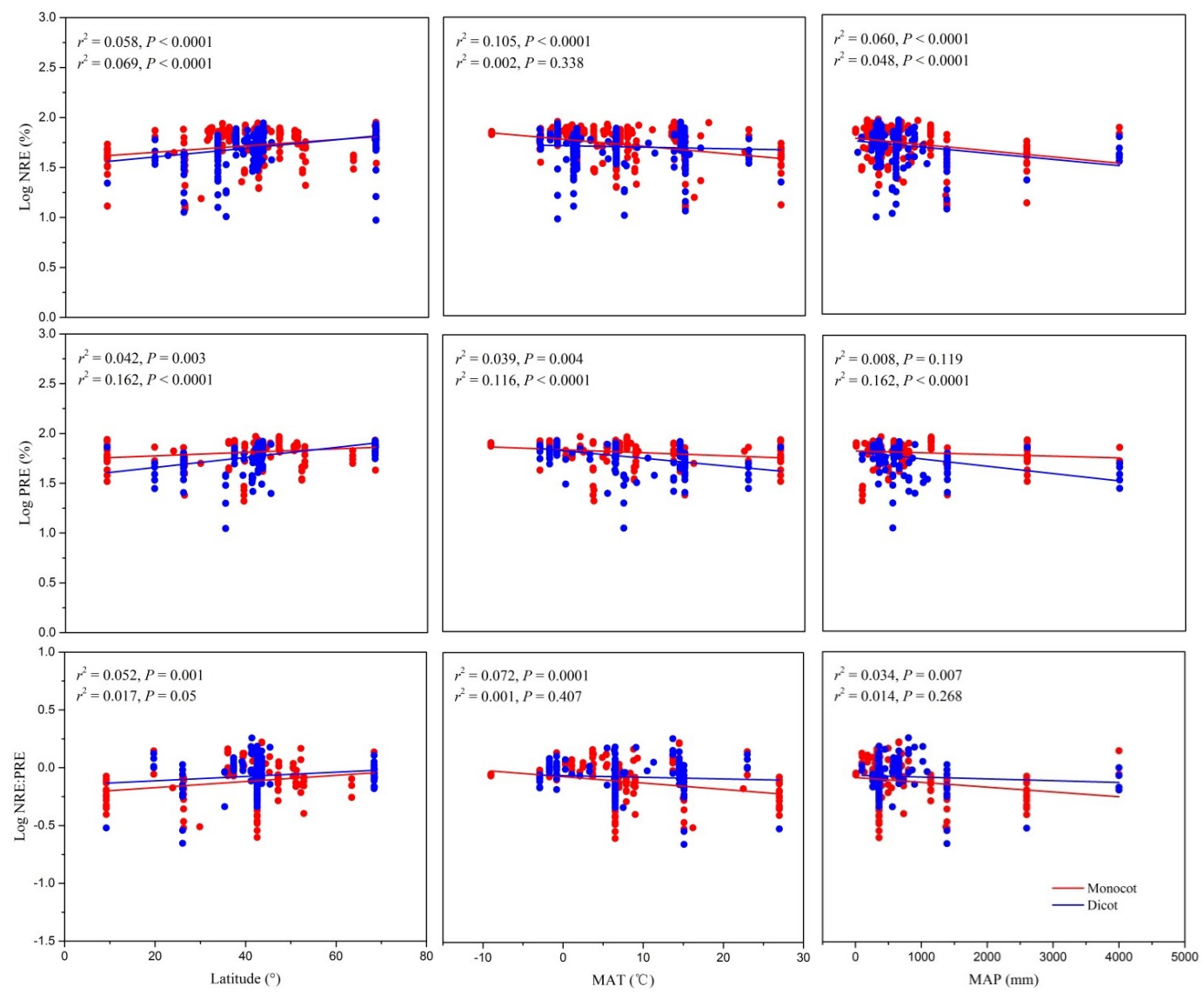